DOI: https://doi.org/10.34069/AI/2021.48.12.8

How to Cite:

Lukin, A., Dubrovina, N., \& Bugakova, M. (2021). Innovation in the system of social relations. Amazonia Investiga, 10(48), 74-80. https://doi.org/10.34069/AI/2021.48.12.8

\title{
Innovation in the system of social relations
}

\section{Инновации в системе общественных отношений}

Received: November 10, 2021

Accepted: December 24, 2021

\begin{abstract}
At present, considerable attention is paid to the issues of innovative development of the economy in the Russian Federation. With the development of market relations, increasingly greater attention is paid to those market mechanisms that contribute to the development of the level of production and consumption of economic benefits, as well as an increase in the level of well-being of the country's citizens. Undoubtedly, the innovative mechanism also belongs to such mechanisms. The purpose of the study is to determine the essence of innovation as a market mechanism within the system of social relations, as well as to determine its role and place as an element of the system of economic relations. To achieve the goal of the study, the structure of social relations was built on the basis of their classification "by the subject of regulation", the functions of innovations as a market mechanism, as well as their interaction with other elements of economic and social relations, were examined, the issues of the formation of an innovative climate were investigated, the factors influencing the demand for innovations in the economy of the Russian Federation were identified.
\end{abstract}

Keywords: system of economic relations, system of social relations, innovation, innovation mechanism, innovation climate.

\footnotetext{
${ }^{27}$ Professor, Samara State University of Economics, Russia.

${ }^{28}$ Head of Department, Samara National Research University, Russia.

${ }^{29} \mathrm{PhD}$ student, Samara National Research University, Russia.
}

-

\section{Аннотация}

В настоящшее время вопросам инновационного развития экономики в Российской Федерации уделяется большое внимание. С развитием рыночных отношений все большее внимание уделяется тем рыночным механизмам, которые способствуют развитию уровня производства и потребления экономических благ, а также увеличению уровня благосостояния граждан страны. Несомненно, к таким механизмам относится и инновационный механизм. Целью исследования является определение сущности инноваций как рыночного механизма в рамках системы общественных отношений, а также определение его роли и места как элемента системы экономических отношений. Для достижения цели исследования построена структура общественных отношений на основании их классификации "по предмету регулирования”, рассмотрены функции инноваций как рыночного механизма, а также их взаимодействие с другими элементами экономических и общественных отношений, исследованы вопросы формирования инновационного климата, определены факторы, влияющие на востребованность инноваций в экономике Российской Федерации.

Ключевые слова: система экономических отношений, система общественных отношений, инновации, инновационный механизм, инновационный климат. 


\section{Introduction}

With the transition to market relations in the Russian Federation, there has been a change in the main priorities of both social relations in general and economic relations in particular. The main postulates, principles and mechanisms of the command-administrative economy became a thing of the past, whereas in contrast entrepreneurship and market mechanisms have come to the fore. At the same time, there has been a tendency to absolutize the value of certain market mechanisms, reaching the end of the search for their alternative options. Such absolutization causes heightened expectations and forces scientists and practitioners to ascribe to economic phenomena, categories and mechanisms functions that they are unable to perform or the functions of other elements of economic relations. The danger of such absolutization lies in the fact that faced with the failure to meet these expectations, researchers either stop research in this direction completely, or continue attempts to adapt phenomena to conditions unusual for them, to the detriment of more promising directions.

A similar metamorphosis has taken place with innovations. Russia has pinned great hopes on the innovative path of development for quite a long time. The term "innovative economy" even appeared and a theory was developed for it (Pospelova, 2012; Safiullina et al, 2014; Akhmetshina \& Mustafin, 2015). However, as the high expectations were not realized into concrete results, interest in innovation began to wane, the course is now headed towards the digital economy (Vishnever et al, 2019), and there is less and less talk about innovation. Meanwhile, a correct understanding of the essence of innovation, as a market mechanism, will allow the most effective use of their potential in the development of the economy. Therefore, the subject of this study is to determine the possibility of innovation in a market economy in terms of its influence on economic relations, as well as to identify factors that influence the development of innovative processes in the economy.

\section{Literature Review}

The relevance of innovation to a market economy is taken at face value. Schumpeter initiated the study of the innovative mechanism, who examined the preconditions for its emergence in his works and developed the basic principles of its operation (Schumpeter, 1912). The innovative aspects of economic management were studied in the second half of the twentieth century by Freeman (Freeman, 1982; Freeman, 1987), Gitman \& Joehnk (1997). The need to develop an innovative environment, in particular education and science, the financial aspects of innovation are reflected in the works of Romer (1990), Lucas (2002). The works of Porter \& Heppelmann (2014), Ulbrich (2015), Kietzmann et al (2015), Röhrs \& Pelc (2016) are concerned with the issues of the impact of innovation on management and on various sectors of the economy and trade; Roud (2018) and Rodríguez-Pose et al, (2021) studied the issues of state support for high-tech industries.

In the Russian Federation, researchers focus on innovative and technological factors that affect the development of the economy and the formation of an innovative climate in the country (Borisov \& Pochukaeva, 2019; Porfiriev, 2015; Faltzman, 2003). A number of works by Russian researchers are devoted to the research potential of the Russian economy (Mindeli \& Khromov, 2012; Frolov \& Ganichev, 2014), concepts and strategies for the development of scienceintensive, high-tech industries (Varshavsky, 2003), as well as issues of assessing and forecasting the prospects for innovative development of the economy (Komkov, 2014). However, in addition to purely applied issues, there are theoretical developments, which, first of all, include studies of the role and place of innovation in the modern economy (Hausman \& Johnston, 2014). As Russian researchers note, despite the implemented state policy measures over the past 25 years, ensuring the effectiveness of the scientific and technological development management system and the formation of an effective national innovation system still remain challenges for the Russian Federation (Idrisov et al, 2018).

There are other variations in the interpretation of the concept of "innovation". The lack of a common understanding of the term "innovation" significantly complicates the understanding of the essence of innovation, the study of this phenomenon, as well as the introduction of innovations into the practice of entrepreneurship. In this paper, we will consider innovation in the framework of their classical understanding, namely, as an economic mechanism that contributes to the introduction of innovations in the activities of business associations, through the creation of a special kind of economic relations that ensure freedom and independence of entrepreneurial choice. Therefore, we will 
further investigate the innovative mechanism in the indicated aspect.

\section{Methodology}

The purpose of this work is to determine the role and place of the innovation mechanism in the system of social and economic relations, the formulation of its functions, and on this basis the development of proposals for the formation of the innovation climate in the country. In the course of the study, the following tasks were consistently solved as follows:

1) the place of the innovation mechanism in the system of economic relations has been clarified;

2) formulated its functions in the system of social relations in general and economic relations in particular;

3) proposals have been developed for the formation of an innovative climate in the country.

In the course of the research, the dialectical method, the method of functional analysis, methods of historical analysis, abstraction, comparison, generalization and synthesis were used. The research was based on the legislative and regulatory acts of the Russian Federation, as well as scientific works of Russian and foreign scientists on the problem under study.

\section{Results and Discussion}

In the USSR, innovation as an economic phenomenon did not exist. Moreover, innovations were viewed as a purely philological concept, meaning a new formation, "a new phenomenon in a language, mainly in the field of morphology, that arises in a given language in a later era of its development" (Prokhorov, 1983). In a Soviet-style command-and-control economy, the terms "scientific and technological progress" and "scientific and technological revolution" were used to reflect progressive changes in economic development. At the same time, one cannot call the Soviet Union a scientifically and technologically backward country.

The emergence of the term "innovation" designating the economic processes of introducing innovations into production, management, distribution, etc. economic benefits associated with market transformations. This mechanism arose on the basis of another market mechanism - an investment one, as a mechanism to ensure that an entrepreneur chooses, in this case, the type of innovation to be introduced in order to minimize his financial risks arising from a high degree of uncertainty about the perception of innovation by consumers.

However, over time, the innovation mechanism began to be perceived more broadly, as almost the only relations that stimulate scientific and technological development and allow the achievements of science and technology in the economic sphere to be realized. This is evidenced by the functions that scientists endow innovation (Sklyarova, 2012; Frolov \& Ganichev, 2014; Postalyuk, 2006). The variety of formulations of the functions of innovation is associated, first of all, with the uncertainty of the place of innovation in the system of social and economic relations. The consequence of this uncertainty is that innovations are assigned functions that are not characteristic of them and which they cannot perform.

According to the Russian scientists, the limitations of the modern ideology of reform processes in the Russian economy are that they are aimed mainly at the redistribution of property and the transformation of public and state property into private, which does not sufficiently affect the transformation of economic relations (Demchenko, 2004; Nusratullin et al, 2019), which fully affected the innovative mechanism.

Initially, production relations took shape in economic relations. Historically, the first production relations were agrarian relations, i.e. agricultural production. Subsequently, production relations began to take shape in the process of production and non-voluntary goods. Monetary relations, originally intended to optimize exchange processes, have gradually transformed into the main instrument for the distribution of produced economic benefits in conditions of limited resources. The development of economic relations took place under the banner of searching for answers to the questions: "how to get some people to produce economic benefits for other people?" and "how to distribute limited goods as fairly as possible among all people?" Traditional relations solve these issues quite simply - production is intended for own consumption. Market relations are based on natural human desires, primarily on the desire of a person to stand out from the general "gray" mass, to get more benefits for himself, to push the boundaries of possibilities, etc. Administrative relations are based on government coercion and government laws. Thus, the economic system of the state depends primarily on which mechanisms are preferred. 


\section{AMAZONDA \\ Dovestiga}

For example, if the prerogative of economic relations, then most likely this is a state with market relations, if it is administrative, then we have a command-administrative economy, etc.

To understand the purpose of the innovation mechanism, it is necessary to determine its place in the system of economic relations. In a very general form, the structure of economic relations in accordance with the attribute of their classification "by the subject of regulation" can be represented in the form of a block diagram (Fig. 1). This figure does not represent all the elements of economic relations, but only those that are necessary to illustrate the concept of work.

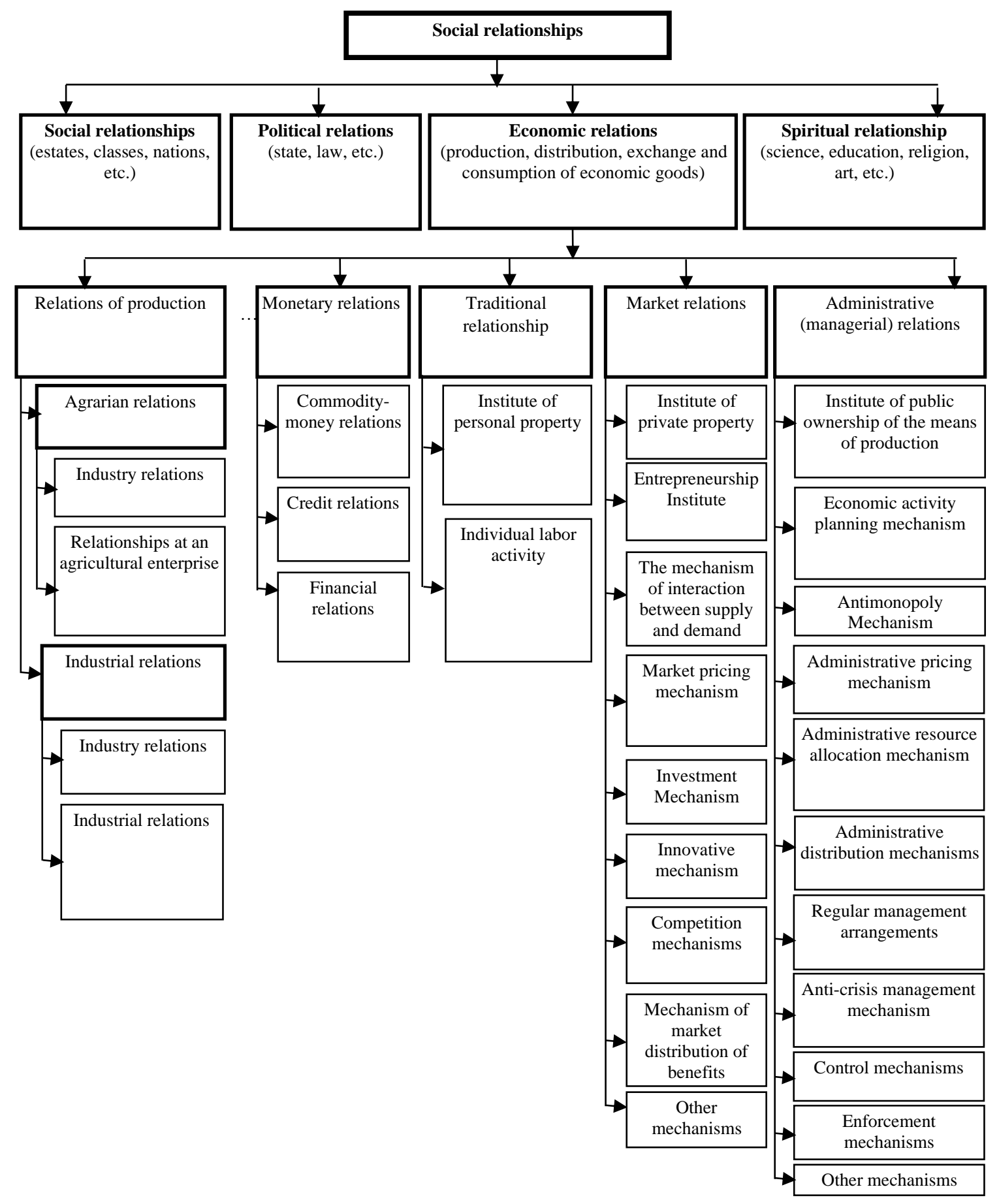

Figure 1. The place of the innovation mechanism in the general structure of economic relations in the system of social relations.

Source: compiled by the authors. 
As can be seen from the figure, the innovative mechanism refers to economic mechanisms based on the desire of a person to obtain the maximum possible benefit from his actions, in this case from the introduction of innovation. Considering that in this system, relations are first formed spontaneously, and only after proving their effectiveness and efficiency are fixed in the form of postulates, laws, etc., the innovative mechanism has also proved its necessity. What is the purpose of the mechanism? Its main functions include:

1. Ensuring the independence of the entrepreneurial choice of the introduced innovation. The innovative mechanism for these purposes uses the advantages of the investment mechanism, creating on its basis its own venture mechanism.

2. Obtaining long-term competitive advantages by a business association. Only innovations make it possible to obtain long-term competitive advantages, since they are the basis for non-price competitive methods. All other techniques, being less costly, provide competitive advantages only for a very short time.

3. Securing intellectual property for ideas and inventions. Mechanisms for the protection of intellectual property, created, first of all, by the state (certificates, patents, copyrights, etc.), as well as by entrepreneurs themselves (know-how, etc.) within the framework of innovation, allow the sale of intellectual achievements and receive material benefits from them.

4. Creation of new mechanisms for introducing innovations into the practice of entrepreneurship. For example, for modern entrepreneurs, there is an increasing demand for a project mechanism that makes it possible to take into account the uncertainty of the external environment and be ready to deal with emerging business risks.

5. Dissemination (diffusion) of scientific achievements and inventions in the business environment. The use of design, venture and other innovative mechanisms that help reduce entrepreneurial risks when introducing innovations attracts entrepreneurs and aims them at updating production, management and other relations within enterprises, which contributes to a wider use of innovations and inventions.

6. Financial and logistical participation in research and development (R\&D), through the entrepreneurial risks reducing mechanisms.
That is, the innovation mechanism allows entrepreneurship to develop more actively, which indirectly, of course, affects the economic development of the country. It is from these positions that it is necessary to perceive the innovative mechanism in order to make the most of its opportunities in the development of economic relations in the state.

Based on the knowledge of the functions of the innovation mechanism in the system of economic relations, it is possible to formulate the main directions of the state's activity in terms of the formation of an innovation climate in the country, which will make it possible to use the capabilities of this mechanism in the most efficient way in scientific and technological development and the creation of an innovative economy.

First, it is to stimulate the development of a venture mechanism in entrepreneurship. One of the main obstacles to the development of venture entrepreneurship in Russia, Russian scientists consider the lack of economic incentives to attract direct investment in high-tech enterprises, which provides an acceptable risk for venture capital investors (Demin \& Khaustov, 2014). In our opinion, it will be quite effective to use the tax mechanism through the provision of incentives to venture capital funds, albeit with strict observance of the conditions for investing in innovations.

Secondly, the participation of the state in regulating the market pricing mechanism, through economic levers, can make the price methods of competition less popular, which in turn should affect the increased interest in innovation as a means of obtaining long-term competitive advantages.

Thirdly, the state should strengthen the protection of the intellectual property of organizations and citizens of the Russian Federation, through simplifying the procedures for passing examinations and obtaining the relevant certification documents, as well as through the implementation of state policy to protect and popularize the results of the activities of domestic inventors.

Fourth, to stimulate and participate on the principles of co-financing and joint material and technical support of scientific and practical developments carried out by entrepreneurs.

Fifth, to develop mechanisms capable of motivating entrepreneurs to renew their 


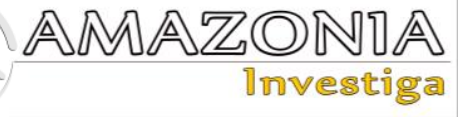

production and material and technical base, through depreciation mechanisms, up to forcing them to do this in some cases through tax and administrative mechanisms.

The implementation of these areas for improving the innovation climate will contribute to the development of an innovation mechanism and, as a result, an increase in the degree of innovation (in the philosophical sense of the word) of the economy.

\section{Conclusions}

The innovative mechanism, being an element of the system of market relations, contributes to the dissemination of the latest achievements of science and technology among entrepreneurs in all spheres of their economic, production, and management activities. However, in order for the innovative mechanism to work, it is necessary to create favorable conditions for this. These conditions can be of twofold origin. On the one hand, the most optimal will be the conditions under which the benefits of entrepreneurs from the introduction of innovations will be obvious and many times exceed the costs of their implementation. On the other hand, given that the expectation of receiving benefits from such an implementation, even with benefits and other preferences from the state, can be quite long and can serve as a serious obstacle for owners and hired managers on the path of updating production, management and other business mechanisms, the state can also provide for a number of coercive measures that facilitate the diffusion of innovations. The main thing is to find a reasonable compromise between incentive and coercion measures when developing the state's innovation policy, which will create an optimal innovation climate in the country.

\section{Bibliographic references}

Akhmetshina, E.R. \& Mustafin, A.N. (2015). Public-private Partnership as a Tool for Development of Innovative Economy. Procedia Economics and Finance, 24, 35-40, https://doi.org/10.1016/S22125671(15)00609-7

Borisov, V.N., \& Pochukaeva, O.V. (2019). Domestic machine building as a factor of scientific and technological development of the Russian economy. MIR, 10(1), 12-25, https://doi.org/10.18184/20794665.2019.10.1.12-25 (in Russian).

Demchenko, L.M. (2004). Problem of correlation of economic and legal relations in K. Marx's philosophy and modern reformatory process.
Vestnik OGU, (10), 22-28, http://vestnik.osu.ru/2004_10/3.pdf (in Russian).

Demin, A.V., \& Khaustov, S.V. (2014). Venture Capital Business in Russia. Bulletin of the University (State University of Management), (11), 87-92.

Faltzman, V.K. (2003). Economic growth. From the past to the future. Moscow: Alpina Publisher (in Russian).

Freeman, C. (1982). The Economics of Industrial Innovation. 2nd Edition. London: Francis Pinter.

Freeman, C. (1987). Technology Policy and Economic Performance: Lessons From Japan. London, New York: Frances Printer Publishers.

Frolov, I.E., \& Ganichev, N.A. (2014). Scientific and technological potential of Russia at the present stage: problems of implementation and development prospects. Problems of Forecasting, $\quad 142, \quad 3-20$, https://cyberleninka.ru/article/n/nauchnotehnologicheskiy-potentsial-rossii-nasovremennom-etape-problemy-realizatsii-iperspektivy-razvitiya (in Russian).

Gitman, L.J., \& Joehnk, M.D. (1997). Fundamentals of Investing. 5th ed. N.Y.: Harper Collins Publishers.

Hausman, A., \& Johnston, W.J. (2014). The role of innovation in driving the economy: Lessons from the global financial crisis. Journal of Business Research, 67(1), 2720-2726, https://doi.org/10.1016/j.jbusres.2013.03.021

Idrisov, G.I., Knyaginin, V.N., Kudrin, A.L., \& Rozhkova, E.S. (2018). New technological revolution: Challenges and opportunities for Russia. Economics, (4), 5-25, https://doi.org/10.32609/0042-8736-2018-45-25 (in Russian).

Kietzmann, J., Pitt, L., \& Berthon, P. (2015). Disruption, Decisions, and Destinations: Enter the Age of 3D Printing and Additive Manufacturing. Business Horizons, 58(2), 209-215. https://doi.org/10.1016/j.bushor.2014.11.005

Komkov, N.I. (2014). Integrated Forecasting of Scientific and Technological Development: Experience and Lessons Learned. Problems of Forecasting, 143, 3-17, https://econpapers.repec.org/article/scn0091 62/15770629.htm (in Russian).

Lucas, R.E. (2002). Lectures on Economic Growth. Cambridge: Harvard University Press.

Mindeli, L.E., \& Khromov, G.S. (2012). Science and Technology Potential of Russia. Part 2. 
Moscow: Institute for Forecasting of RAS (in Russian).

Nusratullin, I.V., Nusratullin, V.K., Gaysina, A.V., \& Habibullin, R.G. (2019). Modern Global Trends of Social and Economic Systems. European Proceedings of Social and Behavioural Sciences, 58, 1435-1445,

https://doi.org/10.15405/epsbs.2019.03.02.1 66

Porfiriev, B.N. (2015). New Global Energy Development Trends - Challenges and Risks of Russia's Integration into the World Economy. Problems of Forecasting, 148, 45-52,

https://ideas.repec.org/a/scn/009162/158461 10.html (in Russian).

Porter, M.E., \& Heppelmann, J.E. (2014). How Smart, Connected Products are Transforming Competition. Harvard Business Review, 92 (11), 64-88, https://hbr.org/2014/11/howsmart-connected-products-are-transformingcompetition

Pospelova, T. (2012). Outlook for the Interaction of Science, Business and State in Building Innovative Economy in Russia. Procedia Social and Behavioral Sciences, 52, 168-178, https://doi.org/10.1016/j.sbspro.2012.09.453

Postalyuk, M.P. (2006). Functional role of innovation relations in the economic system. Problems of Modern Economics, 17/18, http://www.meconomy.ru/art.php?nArtId=960 ～(in Russian).

Prokhorov, A.M. (1983). Soviet Encyclopaedic Dictionary. 2-nd ed. Moscow: Sovetskaya Encyclopedia (in Russian).

Rodríguez-Pose, A., Belso-Martinez, J.A., \& Díez-Vial, I. (2021). Playing the innovation subsidy game: Experience, clusters, consultancy, and networking in regional innovation support. Cities, 119, 103402, https://doi.org/10.1016/j.cities.2021.103402

Röhrs, M., \& Pelc, H. (2016). Aus Erster Hand. Chancen für eine höhere Rohstoffausbeute im Bergbau. Keramische Zeitschrift, 68(3), 152,
https://doi.org/10.1007/BF03400250

(in Germany)

Romer, P.M. (1990). Endogenous Technological Change. Journal of Political Economy, 98(5), 71-102, https://ideas.repec.org/a/ucp/jpolec/v98y199 0i5ps71-102.html

Roud, V. (2018). Understanding the heterogeneity of innovation modes: Performance effects, barriers, and demand for state support. Technological Forecasting and Social Change, 133, 238-253, https://doi.org/10.1016/j.techfore.2018.04.02 5

Safiullina, A., Fatkhiev, A., \& Ulesov, D. (2014). The Main Categories of Innovative Economy. Procedia Economics and Finance, 15, 459-465, https://doi.org/10.1016/S22125671(14)00482-1

Schumpeter, J. (1912). Economic development theory. Leipzig: Duncker \& Humblot (in Germany).

Sklyarova, E.E. (2012). Conceptual model of innovation economy. Socio-economic phenomena and processes, (43), 155-164, https://cyberleninka.ru/article/n/kontseptualn aya-model-innovatsionnoy-ekonomiki (in Russian).

Ulbrich, M. (2015). Changes of Global Value Chains in the Industrial Production Sector. Central European Review of Economics and Finance, 10(4), 35-51, https://www.researchgate.net/publication/31 0327434

Varshavsky, L.E. (2003). Investigation of firms' investment strategies in the markets of capital-intensive and knowledge-intensive products. Moscow: Central Economics and Mathematics Institute of The Russian Academy of Sciences (in Russian).

Vishnever, V.Y., Burganov, R.A., \& Nusratullin, I.V. (2019). Institutional Transformations in the Field of Services in Digital Economy. European Proceedings of Social and Behavioural Sciences, 57, 1759-1768, https://doi.org/10.15405/epsbs.2019.03.178 